\title{
Surgical Resection of Centrally Located Large Hepatocellular Carcinoma
}

\author{
Chih-Hsien Cheng, MD; Ming-Chin Yu, MD; Tsung-Han Wu, MD; Chen-Fang Lee, MD; \\ Kun-Ming Chan, MD; Hong-Shiue Chou, MD; Wei-Chen Lee, MD
}

Background: Centrally located large hepatocellular carcinoma (HCC) is a difficult issue in surgery. These HCCs can be treated by hemi-/extended or central hepatectomies. The aim of this study was to analyze the results of hemi-/extended and central hepatectomies.

Methods: One hundred and four patients with centrally-located large tumors were retrospectively reviewed. Patients were divided into group $1(\mathrm{n}=41)$ with hemi-/extended hepatectomies, and group $2(n=63)$ with central hepatectomies. Characteristics were analyzed between groups and survival rates were calculated.

Results: $\quad$ Parenchyma resection was limited in group 2. The resection margin in $92.6 \%$ of group 2 patients was $<1 \mathrm{~cm}$, compared with $78.9 \%$ of group 1 patients ( $p$ $=0.056)$. The 1- and 5-year disease-free survival rates were $50 \%$ and $38.9 \%$ for group 1 , and $50 \%$ and $15 \%$ for group $2(p=0.279)$. The $1-, 5$-year overall survival rates were $89.5 \%$ and $66.2 \%$ for group 1 and $87.5 \%$ and $53.1 \%$ for group $2(p=0.786)$. Cirrhosis, the preoperative aspartate aminotransferase (AST) level and lower resected liver weight were independent factors impairing survival.

Conclusion: Hemi-/extended and central hepatectomies have comparable complication rates and long-term survival rates for patients with centrally located large HCC. Cirrhosis, the AST level and resected liver weight were independent factors determining long-term survival.

(Chang Gung Med J 2012;35:178-91)

Key words: hepatocellular carcinoma, central hepatectomy, hemi-hepatectomy

$\mathrm{H}$ epatocellular carcinoma (HCC) ranks as the fifth most common malignancy in the world. ${ }^{(1)}$ In Taiwan, HCC is strongly associated with hepatitis $\mathrm{B}$ infection and cirrhosis, and it is the second leading cause of cancer-related death. ${ }^{(2)}$ Although several therapeutic modalities are applied to treat HCC, surgical resection is still the treatment of choice. With recent improvements in surgical techniques and postoperative management, hospital morbidity ranges from 10 to $25 \%$ and hospital mortality has approached zero. ${ }^{(3-5)}$

Centrally located HCCs (segments 4, 5, 8) may require extensive resections because of their relationship to major vascular structures and their deep loca-

From the Division of Transplantation and Liver Surgery, Department of General Surgery, Chang Gung Memorial Hospital at Linkou, Chang Gung University College of Medicine, Taoyuan, Taiwan.

Received: Mar. 29, 2011; Accepted: Oct. 20, 2011

Correspondence to: Dr. Wei-Chen Lee, Division of Transplantation and Liver Surgery, Department of General Surgery, Chang Gung Memorial Hospital at Linkou, Chang Gung University College of Medicine, Taoyuan, Taiwan. 5, Fusing St., Gueishan Township, Taoyuan County 333, Taiwan (R.O.C.) Tel: 886-3-3281200 ext. 3366; Fax: 886-3-3285818; E-mail: weichen@cgmh.org.tw 
tion. Traditionally, these HCCs are resected by right, left, extended right or extended left hepatectomies. Extended or anatomically systematic hepatectomy is recommended based on HCC spread via portal flow. However, these kinds of resections carry a risk of not only significant blood loss but also postoperative liver failure in patients with cirrhosis or poor liver functional reserve. ${ }^{(6,7)}$ Surgical morbidity and mortality rates can be as high as $30 \%$ and $5 \%$, respectively. ${ }^{(8-}$ 10)

The treatment for centrally located large tumors is still in embarrassed circumstances. Radiofrequency ablation (RFA) and percutaneous ethanol injection (PEI) are less effective against tumors greater than 5 $\mathrm{cm}$ than smaller tumors and access is sometimes difficult because of tumor location and adjacent large vessels. Similarly, transarterial chemoembolization (TACE) for centrally located tumors can be difficult because of dual blood supply from the right and left hepatic artery branches. ${ }^{(11,12)}$ Large tumors are poor candidates for liver transplantation and criteria expansion beyond the Milan or University of California at San Francisco criteria is still under evaluation. ${ }^{(13,14)}$ Therefore, limited resection of the central segments remains the choice of treatment, especially, when the tumors are associated with underlying cirrhosis.

Previous reports show that central hepatectomy may achieve the same complication rates and overall survival rates as conventional major hepatectomies. ${ }^{(15,16)}$ However, most reported series included tumors of different sizes and etiologies. The role of surgical resection for centrally -located large HCC is not really clarified. Therefore, the aim of this study is to analyze the early and long- term results of patients with centrally located large HCC, treated with central hepatectomy, or hemi-/extended hepatectomy.

\section{METHODS}

\section{Patients}

From 1999 to 2005,344 patients with large HCC (maximum diameter $>5 \mathrm{~cm}$ ) underwent curative liver resections at Chang-Gung Memorial Hospital. Among them, 104 patients had centrally located tumors which involved segments 4,5 or 8 . (Fig. 1). These patients were divided in two groups.Group $1(n=41)$ had hemi- or extended
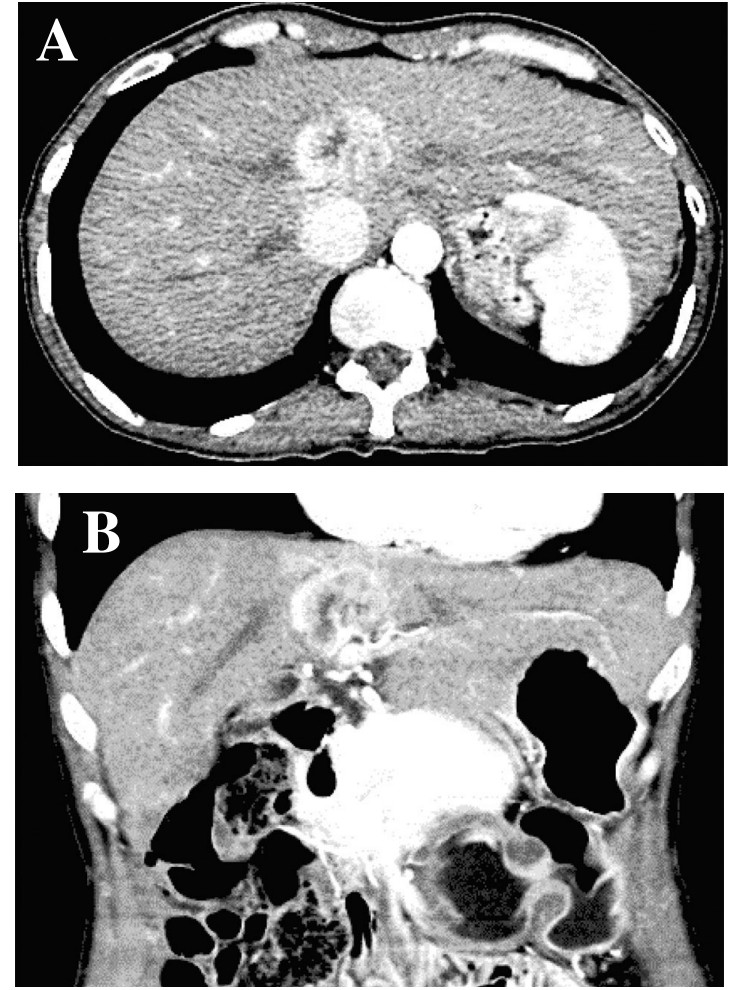

Fig. 1 Abdominal computed tomography images of a $6 \mathrm{~cm}$ tumor located in segment 4.

hepatectomies, and group $2(n=63)$ received central hepatectomies. A central hepatectomy involved resection of Couinaud's segments 4,5 , and 8 (Fig. 2). A right hemihepatectomy included segments 5,6 , 7 , and 8 , a left hemihepatectomy, segments 2,3 , and 4 , an extended right hepatectomy, segments $4,5,6$, 7 , and 8 and an extended left hepatectomy, segments $2,3,4,5$, and 8 . The caudate lobe or segment 1 was resected together with the right or left lobe whenever indicated.

\section{Hepatectomy}

Our algorithm for selecting patients for hepatectomy was based on Makuuchi's criteria. ${ }^{(17)}$ Before surgery, quantitative liver function was evaluated by the indocyanine green retention rate at 15 minutes (ICG $\mathrm{R}_{15}$ ). The extent of liver resection was assessed according to the ICG $\mathrm{R}_{15}$. The ICG $\mathrm{R}_{15}$ was performed by injecting indocyanine green $(0.5 \mathrm{mg} / \mathrm{kg})$ into the patients' peripheral vein and blood samples $(3 \mathrm{ml})$ were drawn from different sites before and fifteen minutes after ICG injection. Next, the ICG $\mathrm{R}_{15}$ 


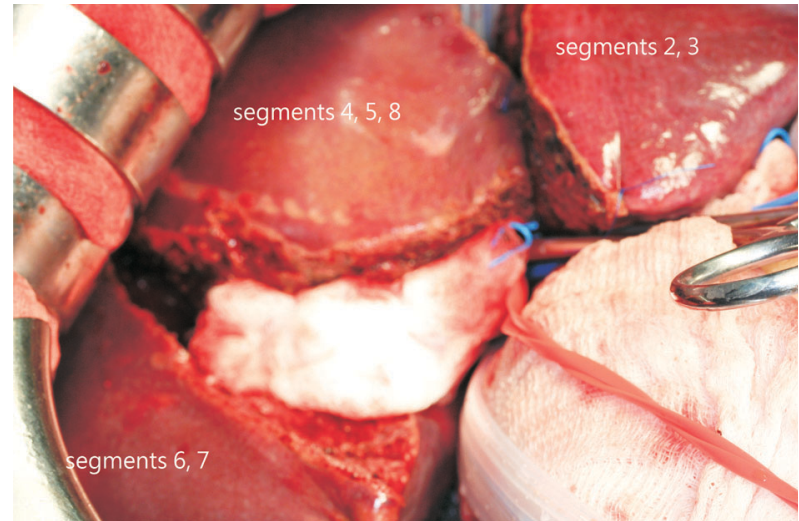

Fig. 2 Central hepatectomy involving segments 4, 5, and 8.

was calculated using spectrophotometric measurements. Both central hepatectomy and hemi or extended hepatectomy involve resection of more than three liver segments and therefore are considered major hepatectomies. The patients were carefully selected and according to our algorithm, and were included in the analysis if they had no ascites, a bilirubin level below twice the upper limit and an ICG clearance rate at 15 minutes of less than $20 \%$. The selection criteria for central hepatectomy or hemi or extended hepatectomy was according to the surgeon's preference and the anatomic location of the tumor. For instance, if the tumor was located more on the right side and close to the right hepatic hilum, a right or extended right hepatectomy was preferred.

During surgery, the abdomen was explored through a subcostal incision with a midline xyphoid extension or through a Mercedes star incision. Intraoperative ultrasonography was routinely performed in order to confirm resectability and evaluate the relationship between the resection line and major vascular structures. Inflow control with the Pringle maneuver was commonly applied intermittently. Hemivascular control was performed in selected right or left hepatectomies. The liver parenchyma was divided according to the surgeon's preference using a clamp-crushing technique or ultrasonic dissector.

\section{Follow up}

Eighty patients were regularly followed up longterm at outpatient clinics and 16 patients were lost to follow-up. Follow-up examinations included liver function tests, alpha-fetoprotein (AFP) levels and ultrasonography every 2-3 months. When tumor recurrence was suspected on ultrasonography, dynamic computed tomography (CT) or hepatic angiography was performed. Repeated hepatic resection, RFA or TACE were the treatments of choice in case of recurrence. The disease-free survival was calculated from the date of surgery to the date when disease recurrence was confirmed with abdominal CT. Overall survival was calculated from the day of surgery until the date of the last follow up.

\section{Analysis of prognostic factors}

To identify independent variables and compare the outcomes of patients who underwent central or conventional hepatectomies, clinical, surgical and pathological factors were analyzed. The clinical factors studied were gender, age, hepatitis $\mathrm{B}$ and $\mathrm{C}$ virus infections, alcohol abuse, liver function (including albumin level, total bilirubin level, transaminase levels, prothrombin time, platelet count, ICG $\mathrm{R}_{15}$, Child-Pugh classification), and presence of esophageal varices and cirrhosis (defined by histopathological findings). The surgical factors included the method of hepatic resection (right/left hemi-/extended versus central hepatectomy), operative time, estimated blood loss and volume of intraoperative blood transfusions. The tumor factors included AFP level, tumor size, encapsulation of the tumor, presence of daughter nodules, vascular invasion, tumor differentiation (according to the Edmonson-Steiner grading system), surgical margin, TNM staging (according to the seventh edition of Cancer Staging Manual of the American Joint Committee on Cancer), and type and treatment of recurrence. The postoperative variables included length of hospital stay, hospital mortality (defined as mortality within 30 days), morbidity, presence of recurrence, and survival time.

\section{Statistical analysis}

Continuous data were expressed as median (interquartile range). Differences in continuous variables between the two treatment groups were assessed using the Mann-Whitney $U$ test. Categorical variables were expressed as percentages and analyzed by the chi square or Fisher exact test, as appropriate. Survival curves were established by the Kaplan-Meier method. Factors with $p<0.2$ in 
univariate analyses were included in multivariable analysis. The final multivariable model was determined using Cox proportional hazard regression in order to identify independent predictors of disease free survival and overall survival. $p<0.050$ was considered statistically significant. All statistical analyses were performed using SPSS ${ }^{\circledR}$ version 13.0 (SPSS, Chicago, Illinois, U.S.A.).

\section{RESULTS}

\section{Patients}

Group 1 and 2 patients had similar age and sex distributions. Fifteen patients (36.6\%) in group 1 and thirty (47.6\%) in group 2 had liver cirrhosis. Between the two groups, there were no significant differences in preoperative liver function, ICG and AFP values, or percentage of patients with liver cirrhosis and viral hepatitis. Three patients $(7.3 \%)$ in group 1 and seven patients $(11.1 \%)$ in group 2 had TACE before the operations. The clinical features of the two patient groups are shown in Table 1.

\section{Differences in surgical variables between groups}

The operative time and estimated blood loss were less in group 2 than group 1 (Table 2). The resected liver weight in group 2 was less than in group 1 as well $(p<0.0001)$. However, there were no differences in intraoperative blood transfusions. Hemivascular control was mostly performed in group 1 and the intermittent Pringle maneuver was commonly used in group 2 . The inflow control time for group 2 was longer than for group 1 (62 vs. 38 minutes, $p=0.012$ ).

\section{Characteristics of the tumors}

The tumors in group 2 were a mean $7.23 \pm 2.34$ $\mathrm{cm}$ in diameter, compared with $8.49 \pm 3.47 \mathrm{~cm}$ in group $1(p=0.047)$. Because central hepatectomies mostly consisted of limited resections, the resection margin was less than $1 \mathrm{~cm}$ in $92.6 \%$ of patients in Group 2, compared with $78.9 \%$ in group 1 ( $p=$ $0.056)$. There were no differences in terms of daughter nodules, tumor differentiation and vascular invasion (Table 3).

\section{Outcomes after surgery}

The demands of the surgical technique for hemi-
Table 1. Characteristics of Patients with Extended/HemiHepatectomy (Group 1) and Central Hepatectomy (Group 2)

\begin{tabular}{|c|c|c|c|}
\hline & $\begin{array}{l}\text { Group } 1 \\
(n=41)\end{array}$ & $\begin{array}{l}\text { Group } 2 \\
(n=63)\end{array}$ & $p$ value \\
\hline Age (years) & $\begin{array}{c}61.00 \\
(50.00-68.50)\end{array}$ & $\begin{array}{c}58.00 \\
(50.00-66.00)\end{array}$ & 0.601 \\
\hline Gender & & & 0.872 \\
\hline Male & $32(78.0 \%)$ & $50(79.4 \%)$ & \\
\hline Female & $9(22.0 \%)$ & $13(20.6 \%)$ & \\
\hline Alcohol & $8(19.5 \%)$ & $14(22.2 \%)$ & 0.741 \\
\hline HBs Ag + & $27 *(73.0 \%)$ & $43(68.3 \%)$ & 0.619 \\
\hline Anti-HCV + & $8^{*}(21.6 \%)$ & $15 * *(24.6 \%)$ & 0.737 \\
\hline Cirrhosis & $15(36.6 \%)$ & $30(47.6 \%)$ & 0.267 \\
\hline History of EV bleeding & 0 & $4(6.3 \%)$ & 0.152 \\
\hline Albumin (mg/dL) & $\begin{array}{c}4.20 \\
(3.60-4.40)\end{array}$ & $\begin{array}{c}4.05 \\
(3.50-4.40)\end{array}$ & 0.882 \\
\hline Total bilirubin $(\mathrm{mg} / \mathrm{dL})$ & $\begin{array}{c}0.80 \\
(0.70-1.30)\end{array}$ & $\begin{array}{c}0.80 \\
(0.70-1.00)\end{array}$ & 0.622 \\
\hline AST (U/dL) & $\begin{array}{c}49.00 \\
(30.75-87.25)\end{array}$ & $\begin{array}{c}38.00 \\
(28.00-62.00)\end{array}$ & 0.196 \\
\hline $\operatorname{ALT}(\mathrm{U} / \mathrm{dL})$ & $\begin{array}{c}49.00 \\
(32.25-71.75)\end{array}$ & $\begin{array}{c}41.00 \\
(24.00-73.00)\end{array}$ & 0.492 \\
\hline PT (sec) & $\begin{array}{c}11.90 \\
(11.23-12.50)\end{array}$ & $\begin{array}{c}11.80 \\
(11.20-12.40)\end{array}$ & 0.520 \\
\hline Platelet (103/uL) & $\begin{array}{c}179.50 \\
(149.25-232.25)\end{array}$ & $\begin{array}{c}198.00 \\
(148.00-235.00)\end{array}$ & 0.748 \\
\hline Creatinine (mg/dL) & $\begin{array}{c}1.00 \\
(0.88-1.10)\end{array}$ & $\begin{array}{c}1.00 \\
(0.90-1.18)\end{array}$ & 0.321 \\
\hline ICG retention rate $_{15}$ & $\begin{array}{c}8.14 \\
(5.88-14.48)\end{array}$ & $\begin{array}{c}8.57 \\
(5.20-13.53)\end{array}$ & 0.723 \\
\hline $\begin{array}{l}\text { Child-Pugh } \\
\text { A } \\
\text { B }\end{array}$ & $\begin{array}{c}37 *(92.50 \%) \\
3 *(7.5 \%)\end{array}$ & $\begin{array}{c}56(88.9 \%) \\
7(11.1 \%)\end{array}$ & 0.737 \\
\hline Pre-op treatment & $3(7.3 \%)$ & $7(11.1 \%)$ & 0.736 \\
\hline
\end{tabular}

Variables are expressed as median (interquartile range) or as number (n) and percent (\%).

Abbreviations: HBsAg: hepatitis B viral surface antigen; HCV: hepatitis C virus; EV: esophageal varices; AST: aspartate aminotransferase; ALT: alanine aminotransferase; PT: prothrombin time; ICG: indocyanine green. 
Table 2. Surgical Variables for Group 1 and Group 2

\begin{tabular}{|c|c|c|c|}
\hline & $\begin{array}{l}\text { Group } 1 \\
(\mathrm{n}=41)\end{array}$ & $\begin{array}{l}\text { Group } 2 \\
(\mathrm{n}=63)\end{array}$ & $p$ value \\
\hline $\begin{array}{l}\text { Operative time } \\
\text { (min) }\end{array}$ & $\begin{array}{c}316.00 \\
(250.00-381.50)\end{array}$ & $\begin{array}{c}230.00 \\
(180.00-294.00)\end{array}$ & $<0.0001$ \\
\hline $\begin{array}{l}\text { Estimated blood } \\
\text { loss }(\mathrm{mL})\end{array}$ & $\begin{array}{c}750.00 \\
(300.00-1700.00)\end{array}$ & $\begin{array}{c}500 \\
(100.00-750.00)\end{array}$ & 0.004 \\
\hline $\begin{array}{l}\text { Intraoperative blood } \\
\text { transfusion }(\mathrm{mL})\end{array}$ & $\begin{array}{c}600.00 \\
(300.00-900.00)\end{array}$ & $\begin{array}{c}600.00 \\
(375.00-900.00)\end{array}$ & 0.899 \\
\hline $\begin{array}{c}\text { Resected liver } \\
\text { weight }(\mathrm{g})\end{array}$ & $\begin{array}{c}590.00 \\
(367.50-995.00)\end{array}$ & $\begin{array}{c}226.50 \\
(178.75-363.75)\end{array}$ & $<0.0001$ \\
\hline
\end{tabular}

Variables are expressed as median (interquartile range).

Table 3. Characteristics of Tumors in Group 1 and Group 2

\begin{tabular}{|c|c|c|c|}
\hline & $\begin{array}{l}\text { Group } 1 \\
(\mathrm{n}=41)\end{array}$ & $\begin{array}{l}\text { Group } 2 \\
(\mathrm{n}=63)\end{array}$ & $p$ value \\
\hline $\operatorname{AFP}(\mathrm{ng} / \mathrm{mL})($ median$)$ & $\begin{array}{c}82 \\
(7.00-989.50)\end{array}$ & $\begin{array}{c}58 \\
(8.00-925.00)\end{array}$ & 0.760 \\
\hline Tumor size $(\mathrm{cm})$ & $\begin{array}{c}8.00 \\
(5.50-10.25)\end{array}$ & $\begin{array}{c}6.50 \\
(5.50-8.50)\end{array}$ & 0.156 \\
\hline Encapsulation & $26(63.4 \%)$ & $45(71.4 \%)$ & 0.391 \\
\hline Daughter nodules & $16(39.0 \%)$ & $20(31.7 \%)$ & 0.446 \\
\hline Vascular invasion & & & 0.153 \\
\hline Macro & $13(31.7 \%)$ & $12(19.0 \%)$ & \\
\hline Micro & $6(14.6 \%)$ & $18(28.6 \%)$ & \\
\hline Absent & $22(53.7 \%)$ & $33(52.4 \%)$ & \\
\hline Tumor differentiation & & & 0.569 \\
\hline I-II & $14(34.1 \%)$ & $25(39.7 \%)$ & \\
\hline III-IV & $27(65.9 \%)$ & $38(60.3 \%)$ & \\
\hline Section margin & & & 0.056 \\
\hline$\leqq 1 \mathrm{~cm}$ & $30(78.9 \%)$ & $50(92.6 \%)$ & \\
\hline$>1 \mathrm{~cm}$ & $8(21.1 \%)$ & $4(7.4 \%)$ & \\
\hline \multicolumn{4}{|l|}{ TNM } \\
\hline Stage 1 & $18(43.9 \%)$ & $24(38.1 \%)$ & 0.165 \\
\hline Stage 2 & $2(4.9 \%)$ & $10(15.9 \%)$ & \\
\hline Stage $3 a$ & $8(19.5 \%)$ & $14(22.2 \%)$ & \\
\hline Stage $3 b$ & $13(31,70 \%)$ & $12(19 \%)$ & \\
\hline Stage $3 c$ & 0 & $3(4.8 \%)$ & \\
\hline
\end{tabular}

Variables are expressed as median (interquartile range) or as number (n) and percent (\%).

Abbreviation: AFP: alpha-fetoprotein. /extended right or left hepatectomy and central hepatectomy were different. The preservation of liver volume after hemi-/extended hepatectomy and central hepatectomy was also totally different. To compare the outcomes of group 1 and 2 patients, the complication rates and survival rates of both groups were calculated. The mean postoperative hospital stay was $11.2 \pm 4.2$ and $10.0 \pm 6.6$ days for groups 1 and 2, respectively. Six complications occurred in group 1 and eight in group 2. These complications included immediate liver failure after hepatectomy $(n=4)$, biliary leakage $(n=2)$, upper gastrointestinal bleeding $(n=2)$, intraabdominal hematoma $(n=2)$, intraabdominal bleeding $(n=1)$, pneumonia $(n=1)$, intraabdominal abscess $(n=1)$ and surgical site infection $(n=1)$. Both groups had two patients with liver failure and one with biliary leakage. All of them died of subsequent multiorgan failure because the surgical complications were superimposed on infection. Overall hospital mortality was $7.3 \%$ forgroup 1 and $7.9 \%$ for group 2 (Table 4 ). After excluding patients with hospital mortality, the duration of follow- up ranged from 1.2 to 99.7 months with a median of 30.6 months. The survival rates for the two groups were calculated and the results showed that the disease-free and overall survival curves were comparable between groups. The cumulative 1- and 5 -year disease-free rates were $50 \%$, and $38.9 \%$ for group 1, and $50 \%$ and $15 \%$ for group 2 (Fig. $3, p=$

Table 4. Postoperative Complications and Tumor Recurrence for Group 1 and 2

\begin{tabular}{lccc}
\hline & $\begin{array}{c}\text { Group 1 } \\
(\mathrm{n}=41)\end{array}$ & $\begin{array}{c}\text { Group 2 } \\
(\mathrm{n}=63)\end{array}$ & $p$ value \\
\hline $\begin{array}{l}\text { Postoperative hospital } \\
\text { stay (days) }\end{array}$ & $\begin{array}{c}10.00 \\
(8.00-12.00)\end{array}$ & $\begin{array}{c}8.00 \\
(7.00-9.00)\end{array}$ & 0.001 \\
& & & \\
Postoperative complications & $6(14.6 \%)$ & $8(12.7 \%)$ & 0.777 \\
& $3(7.3 \%)$ & $5(7.9 \%)$ & 1.000 \\
Hospital mortality & $17(41.5 \%)$ & $39(61.9 \%)$ & 0.094 \\
& & & 0.768 \\
Recurrence & & & \\
& $4(23.5 \%)$ & $14(35.9 \%)$ & \\
Recurrence type & $9(52.9 \%)$ & $19(48.7 \%)$ & \\
$\quad \begin{array}{l}\text { Single } \\
\text { Multiple }\end{array}$ & $1(5.9 \%)$ & $2(5.1 \%)$ & \\
$\quad \begin{array}{l}\text { Intraabdominal } \\
\text { Distant metastasis }\end{array}$ & $3(17.6 \%)$ & $4(10.3 \%)$ & \\
\hline
\end{tabular}

Variables are expressed as median (interquartile range) or as number (n) and percent (\%). 
0.279 ). The 1- and 5-year overall survival rates were $89.5 \%$ and $66.2 \%$ for group 1 and $87.5 \%$ and $53.1 \%$ for group 2 (Fig. 4, $p=0.786$ ). Among the patients with tumor recurrence, $82.1 \%$ of the recurrences were within the liver, of which $39.3 \%$ were in the same lobe or near the resection margin and $60.7 \%$ developed in other lobes. The difference in the recurrence pattern and type of treatment for recurrences was not statistically significant between groups. Of the patients with recurrence, $58.9 \%$ were treated with TACE, 5.4\% received RFA or PEI, and 7.1\% underwent another resection. The four patients with opera-

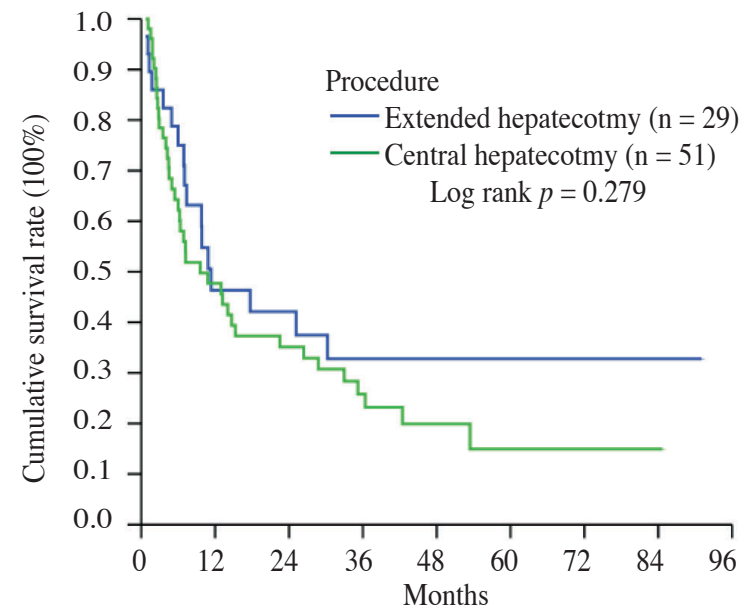

Fig. 3 Disease-free survival rates for patients with hemi/extended or central hepatectomy for centrally located large HCC.

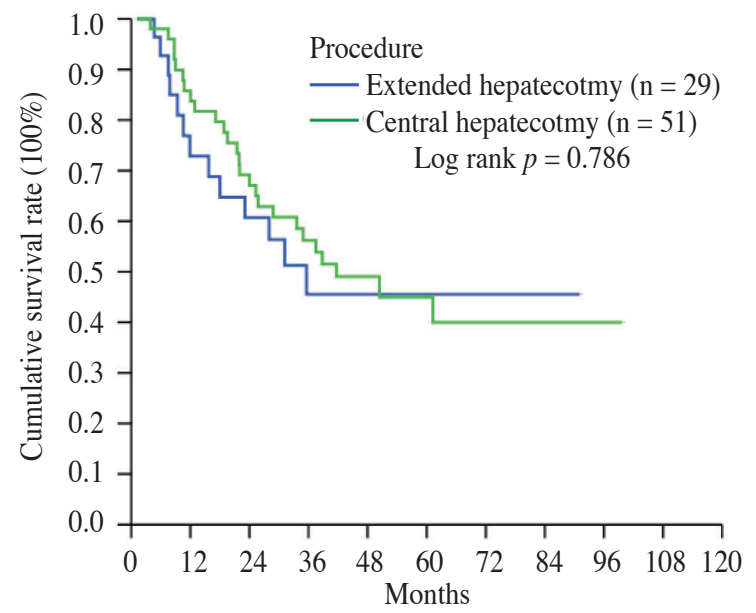

Fig. 4 Overall survival rates for patients with hemi-/extended or central hepatectomy for centrally located large HCC. tions for tumor recurrence were in group 2. In univariate analysis, age above 65 years, cirrhosis, an aspartate aminotransferase (AST) level less than 34 $\mathrm{U} / \mathrm{L}$, and an albumin level less than $3.5 \mathrm{~g} / \mathrm{dL}$ were significant predictors for recurrence. Age above 65 years, cirrhosis, an AST level less than $34 \mathrm{U} / \mathrm{L}$, an albumin level less than $3.5 \mathrm{~g} / \mathrm{dL}$, tumor encapsulation, tumor grading, tumor more than $6.5 \mathrm{~cm}$ in diameter, resected liver weight more than $330 \mathrm{~g}$ and method of inflow control were all significant factors predicting poor overall survival. In multivariate analysis, cirrhosis, a low AST level and low resected liver weight were independent factors contributing to overall survival (Tables 5 and 6).

\section{DISCUSSION}

The treatment of patients with centrally located HCCs remains under debate. ${ }^{(18)}$ Hemi- or extended hepatectomies are the traditional approaches. With these major hepatectomies, a large volume of functional liver parenchyma is sacrificed and it is well known that the number of resected segments has a negative impact on perioperative morbidity and mortality. ${ }^{(19-21)}$ This is especially critical in cirrhotic patients, where excessive resections may lead to postoperative liver failure and associated complications. In our study, only two patients (4.9\%) in group 1 died of immediate postoperative liver failure and this was comparable to the reported rate of $6-10 \%$ in the literature. ${ }^{(10)}$

Central hepatectomy, the other surgical alternative, preserves more liver parenchyma and theoretically is associated with a better recovery in the short term. However, central hepatectomy is a technically demanding surgery. The presence of two hepatic parenchymal transections with proximity to important vascular structures makes it technically more complex than hemihepatectomies. Moreover, large tumors located in the central portion of the liver are associated with an increased risk of intraoperative bleeding. To reduce the operative blood loss, we routinely employed the Pringle maneuver to control the blood inflow. The middle hepatic vein was carefully evaluated by CT scan preoperatively and ultrasound intraoperatively. During parenchymal dissection, care was especially taken with the middle hepatic vein to reduce blood loss. In this series, only $12 \%$ of patients required blood transfusions intraoperatively. 
Table 5. Univariate and Multivariate Analysis of Risk Factors for Disease-free Survival

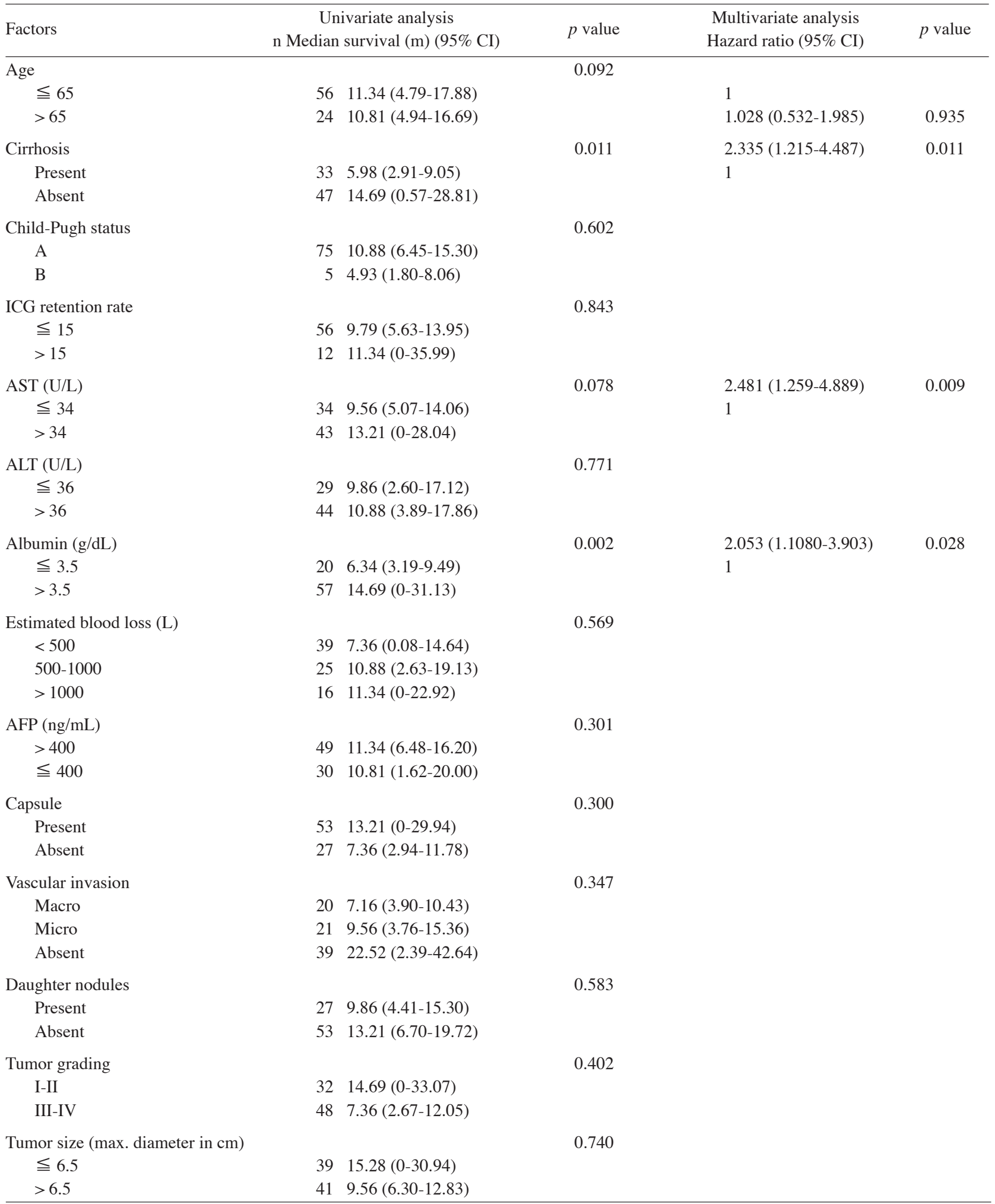


Table 5. Univariate and Multivariate Analysis of Risk Factors for Disease-free Survival (continued)

\begin{tabular}{|c|c|c|c|c|}
\hline Factors & $\begin{array}{c}\text { Univariate analysis } \\
\mathrm{n} \text { Median survival (m) }(95 \% \mathrm{CI})\end{array}$ & $p$ value & $\begin{array}{l}\text { Multivariate analysis } \\
\text { Hazard ratio }(95 \% \mathrm{CI})\end{array}$ & $p$ value \\
\hline Resected liver weight (g) & & 0.767 & & \\
\hline$\leqq 330$ & $3814.03(0.94-27.12)$ & & & \\
\hline$>330$ & $419.79(5.74-13.84)$ & & & \\
\hline $\operatorname{Margin}(\mathrm{cm})$ & & 0.348 & & \\
\hline$\leqq 1$ & $7010.88(6.12-15.64)$ & & & \\
\hline$>1$ & $107.36(0.00-16.79)$ & & & \\
\hline Inflow control & & 0.630 & & \\
\hline Pringle maneuver & $3615.28(0-35.73)$ & & & \\
\hline Hemivascular & $157.03(4.73-9.34)$ & & & \\
\hline None & $2712.98(5.64-20.32)$ & & & \\
\hline TNM & & 0.280 & & \\
\hline Stage 1 & $30 \quad 25.15(10.83-39.47)$ & & 1 & \\
\hline Stage 2 & $104.50(0-13.77)$ & & $0.902(0.351-2.318)$ & 0.830 \\
\hline Stage $3 \mathrm{a}$ & $189.86(2.20-17.51)$ & & $1.251(0.606-2.581)$ & 0.545 \\
\hline Stage $3 b$ & $207.16(3.90-10.43)$ & & $1.999(0.914-4.371)$ & 0.083 \\
\hline Stage $3 \mathrm{c}$ & 24.43 & & $2.412(0.477-12.199)$ & 0.287 \\
\hline Procedure & & 0.279 & & \\
\hline Extended hepatectomy & $2911.34(2.21-20.46)$ & & 1 & \\
\hline Central hepatectomy & $519.56(2-44-16.68)$ & & $1.128(0.579-2.196)$ & 0.724 \\
\hline
\end{tabular}

Abbreviations: ICG: indocyanine green; AST: aspartate aminotransferase; ALT: alanine aminotransferase; AFP: alpha-fetoprotein.

Table 6. Univariate and Multivariate Analysis of Risk Factors for Overall Survival

\begin{tabular}{|c|c|c|c|c|}
\hline Factors & $\begin{array}{c}\text { Univariate analysis } \\
\mathrm{n} \text { Median survival }(\mathrm{m})(95 \% \mathrm{CI})\end{array}$ & $p$ value & $\begin{array}{l}\text { Multivariate analysis } \\
\text { Hazard ratio }(95 \% \mathrm{CI})\end{array}$ & $p$ value \\
\hline Age & & 0.087 & & \\
\hline$\leqq 65$ & $56-$ & & 1 & \\
\hline$>65$ & $2434.91(16.19-53.64)$ & & $2.153(0.576-3.662)$ & 0.110 \\
\hline Cirrhosis & & 0.082 & & \\
\hline Present & $3328.83(13.67-43.99)$ & & $3.152(1.302-7.627)$ & 0.011 \\
\hline Absent & $47-$ & & 1 & \\
\hline Child-Pugh status & & 0.368 & & \\
\hline A & $75 \quad 41.65(14.32-68.98)$ & & & \\
\hline B & $521.46(0-48.62)$ & & & \\
\hline ICG retention rate & & 0.759 & & \\
\hline$\leqq 15$ & $5633.63(17.78-49.47)$ & & & \\
\hline$>15$ & $1261.24(16.66-105.83$ & & & \\
\hline AST (U/L) & & 0.088 & & \\
\hline$\leqq 34$ & $3424.03(10.84-37.21)$ & & $3.400(1.356-8.522)$ & 0.009 \\
\hline$>34$ & $4361.25(-)$ & & 1 & \\
\hline ALT (U/L) & & 0.740 & & \\
\hline$\leqq 36$ & $2937.47(12.98-61.97)$ & & & \\
\hline$>36$ & $4435.57(5.73-69.41)$ & & & \\
\hline Albumin (g/dL) & & 0.005 & & \\
\hline$\leqq 3.5$ & $2021.99(4.99-38.99)$ & & $2.153(0.841-5.507)$ & 0.110 \\
\hline$>3.5$ & $57-$ & & 1 & \\
\hline
\end{tabular}


Table 6. Univariate and Multivariate Analysis of Risk Factors for Overall Survival (continued)

\begin{tabular}{|c|c|c|c|c|c|}
\hline \multirow{2}{*}{$\begin{array}{l}\text { Factors } \\
\text { Estimated blood loss (L) }\end{array}$} & \multicolumn{2}{|c|}{$\begin{array}{c}\text { Univariate analysis } \\
\text { n Median survival (m) }(95 \% \mathrm{CI})\end{array}$} & $p$ value & \multirow[t]{2}{*}{$\begin{array}{l}\text { Multivariate analysis } \\
\text { Hazard ratio }(95 \% \mathrm{CI})\end{array}$} & \multirow[t]{2}{*}{$p$ value } \\
\hline & & & 0.710 & & \\
\hline$<500$ & 39 & $50.40(-)$ & & & \\
\hline $500-1000$ & 25 & $34.91(0-84.83)$ & & & \\
\hline$>1000$ & 16 & $35.57(20.47-50.67)$ & & & \\
\hline AFP (ng/mL) & & & 0.260 & & \\
\hline$>400$ & 49 & $34.91(11.36-58.46)$ & & & \\
\hline$\leqq 400$ & 30 & - & & & \\
\hline Capsule & & & 0.005 & & \\
\hline Present & 53 & - & & 1 & \\
\hline Absent & 27 & $23.07(17.74-28.41)$ & & $1.596(0.537-4.744)$ & 0.400 \\
\hline Vascular invasion & & & 0.211 & & \\
\hline Macro & 20 & $23.07(15.84-30.31)$ & & & \\
\hline Micro & 21 & $41.65(-)$ & & & \\
\hline Absent & 39 & $61.24(-)$ & & & \\
\hline Daughter nodules & & & 0.556 & & \\
\hline Present & 27 & $37.47(26.38-48.57)$ & & & \\
\hline Absent & 53 & $61.24(-)$ & & & \\
\hline Tumor grading & & & 0.191 & & \\
\hline I-II & 32 & - & & 1 & \\
\hline III-IV & 48 & $33.63(18.25-49.01)$ & & $2.165(0.849-5.523)$ & 0.106 \\
\hline Tumor size (max. diameter in $\mathrm{cm}$ ) & & & 0.017 & & \\
\hline$\leqq 6.5$ & 39 & - & & 1 & \\
\hline$>6.5$ & 41 & $25.74(16.69-34.78)$ & & $2.237(0.799-6.259)$ & 0.125 \\
\hline Resected liver weight (g) & & & 0.012 & & \\
\hline$\leqq 330$ & 38 & - & & 1 & \\
\hline$>330$ & 41 & $25.31(14.79-35.83)$ & & $3.425(1.038-11.301)$ & 0.043 \\
\hline $\operatorname{Margin}(\mathrm{cm})$ & & & 0.617 & & \\
\hline$\leqq 1$ & 70 & $38.79(9.78-67.80)$ & & & \\
\hline$>1$ & 10 & $50.40(-)$ & & & \\
\hline Inflow control & & & 0.125 & & \\
\hline Pringle maneuver & 36 & $61.24(-)$ & & 1 & \\
\hline Hemivascular & 15 & $23.07(3.78-42.37)$ & & $3.659(0.657-20.378)$ & 0.139 \\
\hline None & 27 & $50.40(-)$ & & $1.584(0.517-4.852)$ & \\
\hline TNM & & & 0.314 & & \\
\hline Stage 1 & 30 & - & & 1 & \\
\hline Stage 2 & 10 & $28.83(-)$ & & 1.785 (0.399-7.989) & 0.448 \\
\hline Stage $3 a$ & 18 & $34.47(27.72-47.23)$ & & $0.907(0.292-2.817)$ & 0.866 \\
\hline Stage $3 b$ & 20 & $23.07(15.84-30.31)$ & & $1.226(0.360-4.175)$ & 0.744 \\
\hline Stage $3 c$ & 2 & $12.92(-)$ & & $3.870(0.474-31.605)$ & 0.207 \\
\hline Procedure & & & 0.786 & & \\
\hline Extended hepatectomy & 29 & $35.57(-)$ & & 1 & \\
\hline Central hepatectomy & 51 & $41.65(21.70-61.60)$ & & $3.160(0.714-13.985)$ & 0.129 \\
\hline
\end{tabular}

Abbreviations: ICG: indocyanine green; AST: aspartate aminotransferase; ALT: alanine aminotransferase; AFP: alpha-fetoprotein. 
Giuliante et al. demonstrated that preliminary control of the hepatic veins during central hepatectomy was associated with reduced operative bleeding and a lower blood transfusion rate. ${ }^{(22)}$ Extrahepatic outflow control of the main hepatic veins and the infrahepatic vena cava could reduce the risk of hemorrhage from backflow bleeding. However, complete mobilization of the right lobe and retraction of the central segments may be difficult with big tumors. Alternatively, an anterior approach has been shown to reduce blood loss, ${ }^{(23)}$ and this technique is already employed in central hepatectomies in our institution. ${ }^{(24)}$

Bile leakage and liver failure are the most common complications in central hepatectomy. In our series, one patient had postoperative bile leakage $(1.5 \%)$ and two patients died of liver failure $(3.1 \%)$ after central hepatectomies. However, $47.6 \%$ of the patients in the central hepatectomy group had liver cirrhosis and the mean tumor size was $7.24 \pm 2.35$ $\mathrm{cm}$. These two characteristics per se may carry a considerable risk of postoperative liver failure and complications. ${ }^{(25)}$ In the literature, the incidence of complications after central hepatectomy ranges from 17 to $26.3 \%$ and the reported surgical mortality is between 0 and $6.25 \% .{ }^{(18)}$ Our results are compatible with those of previous reports. Furthermore, the central hepatectomy group had a shorter postoperative hospital stay than the extended/hemi-hepatectomy group.

Centrally located tumors are often close to the hepatic hilum and the main hepatic veins. Therefore, surgical resection of these tumors is likely to be associated with small margins, especially if the tumors are larger than $5 \mathrm{~cm}$. In our experience, extended hepatectomy only provides a slightly higher proportion of patients with a resection margin $>1 \mathrm{~cm}$ (21.1\% versus $7.4 \%, p=0.056)$. As mentioned previously, there is currently a trend toward limited hepatic resections to prevent postoperative liver failure. The number of hepatic segments resected is considered to have a negative impact on perioperative morbidity and mortality and the preservation of liver function is a priority. ${ }^{(19-21)}$ This was particularly reflected in the multivariate analysis, where a resected liver weight more than $330 \mathrm{~g}$ was a significant factor for poor long term survival. ${ }^{(26-28)}$

Additionally, it is also believed that most intrahepatic recurrences arise from multicentric carcino- genesis and are distant from the resection margin. Therefore, although it is better to obtain a resection margin $>1 \mathrm{~cm}$, the importance of a wide margin for centrally located large tumors still needs to be evaluated. . $^{(2,29-31)}$

At present, patients with large HCC represent poor candidates for liver transplantation and partial hepatectomy remains the only treatment to provide consistent disease-free and overall survival. Portal vein embolization is an optional procedure that increases the remaining liver reserve and the safety of major hepatectomy without compromising longterm outcomes. ${ }^{(32,33)}$ However, with centrally located large tumors; it is difficult to wait for liver hypertrophy after either side of the portal vein is embolized. Direct surgical resection remains the mainstay of treatment. Because cirrhosis and poor hepatic reserve are often associated with HCC, this surgical strategy is the only one which allows for preservation of adequate residual liver volume and function. Thus, careful patient selection and surgical experience is mandatory.

The 5-year disease-free and overall survival rates after central hepatectomy for large HCCs were comparable to those of hemi-/extended hepatectomies. One possible explanation is their similar recurrence pattern and use of aggressive treatment with TACE, RFA and even repeat resection. The cumulative 5 -year disease-free rates were $38.9 \%$ for patients with extended resections and $15 \%$ for patients with central resections $(p=0.279$ ). Although it was not statistically significant, this represented a trend. The patients' baseline characteristics, surgical factors and tumor factors were not different between groups, but one possible factor may be the higher proportion of patients with liver cirrhosis and Child B status in the central hepatectomy group. Cirrhosis is associated with higher recurrence rates ${ }^{(34)}$ because of strong hepatic inflammatory activity and progressive liver disease, ${ }^{(35)}$ which may be associated with continuing carcinogenesis. ${ }^{(19,36)}$

Cirrhosis and low preoperative AST and albumin levels were other independent factors for tumor recurrence and overall survival. Mild to moderate elevations of liver enzymes are commonplace in patients with cirrhosis and HCC. They are sensitive indicators of the presence of liver disease and may lead to prompt examinations and earlier tumor diagnosis. Conversely, we presume that a low preopera- 
tive AST level was a negative factor affecting survival because it may be associated with delayed diagnosis and treatment. Hypoalbuminemia has been reported to be a risk factor for perioperative morbidity ${ }^{(37-40)}$ or recurrence after resection. ${ }^{(41)}$ It is a multifactorial indicator for the degree of liver disease, nutritional status or a stress response. It is also associated with impairment of macrophage activation and a decreased innate immune response. ${ }^{(42)}$ The presence of cirrhosis further worsens the state of protein-calorie malnutrition and increased catabolism. Liver resection in these patients further decreases the functional liver mass, and postoperative sepsis, nutritional deprivation and compromised immunity tend to cause further deterioration of liver function. The deterioration of liver function associated with a low regeneration capacity and impaired immune response may a posteriori contribute to tumor recurrence.

The long term survival for the central hepatectomy group was comparable with those in previous series and even with those treated with other types of minor resections. The debate still remains whether patients with large central tumors should receive a central hepatectomy even with its technical difficulties. The conservation of more nontumor liver parenchyma a priori is presumed to be important for patient survival, but at present, most series have failed to confirm this assumption. In our experience, a central hepatectomy preserves more liver parenchyma and finally the resected liver weight was an independent prognostic factor for survival. However, a central hepatectomy in cirrhotic patients with large tumors still carries a high risk of postoperative complications. We believe that this procedure requires extensive experience in liver surgery in a high-volume center.

\section{Conclusion}

The surgical strategy for centrally located largesized HCC is still controversial. In this study, the overall surgical complication rate, hospital mortality, and long-term disease-free and survival rates for central hepatectomy and extended/hemi-hepatectomy were comparable. Cirrhosis, a low preoperative AST level and a low resected liver weight were independent factors determining long-term survival.

\section{Acknowledgements}

We would like to thank Ms Shu Fang Huang for her assistance in the statistical analyses.

\section{REFERENCES}

1. Colombo M, Sangiovanni A. Etiology, natural history and treatment of hepatocellular carcinoma. Antiviral Res 2003;60:145-50.

2. Yeh CN, Lee WC, Jeng LB, Chen MF. Hepatic resection for hepatocellular carcinoma in Taiwan. Eur J Surg Oncol 2002;28:652-6.

3. Torzilli G, Makuuchi M, Inoue K, Takayama T, Sakamoto Y, Sugawara Y, Kubota K, Zucchi A. No-mortality liver resection for hepatocellular carcinoma in cirrhotic and noncirrhotic patients: is there a way? A prospective analysis of our approach. Arch Surg 1999;134:984-92.

4. Yeh CN, Chen MF, Lee WC, Jeng LB. Prognostic factors of hepatic resection for hepatocellular carcinoma with cirrhosis: univariate and multivariate analysis. J Surg Oncol 2002;81:195-202.

5. Lee WC, Jeng LB, Chen MF. Estimation of prognosis after hepatectomy for hepatocellular carcinoma. Br J Surg 2002;89:311-6

6. Hanazaki K, Kajikawa S, Shimozawa N, Shimada K, Hiraguri M, Koide N, Adachi W, Amano J. Hepatic resection for large hepatocellular carcinoma. Am J Surg 2001;181:347-53.

7. Chen XP, Qiu FZ, Wu ZD, Zhang BX. Chinese experience with hepatectomy for huge hepatocellular carcinoma. Br J Surg 2004;91:322-6.

8. Brancatisano R, Isla A, Habib N. Is radical hepatic surgery safe? Am J Surg 1998;175:161-3.

9. Zhou L, Rui JA, Wang SB, Chen SG, Qu Q, Chi TY, Wei X, Han K, Zhang N, Zhao HT. Outcomes and prognostic factors of cirrhotic patients with hepatocellular carcinoma after radical major hepatectomy. World J Surg 2007;31: 1782-7.

10. Poon RT, Fan ST, Lo CM, Liu CL, Lam CM, Yuen WK, Yeung C, Wong J. Extended hepatic resection for hepatocellular carcinoma in patients with cirrhosis: is it justified? Ann Surg 2002;236:602-11.

11. Takaki H, Yamakado K, Nakatsuka A, Fuke H, Murata K, Shiraki K, Takeda K. Radiofrequency ablation combined with chemoembolization for the treatment of hepatocellular carcinomas $5 \mathrm{~cm}$ or smaller: risk factors for local tumor progression. J Vasc Interv Radiol 2007;18:856-61.

12. Lencioni R. Loco-regional treatment of hepatocellular carcinoma. Hepatology 2010;52:762-73.

13. Mazzaferro V, Regalia E, Doci R, Andreola S, Pulvirenti A, Bozzetti F, Montalto F, Ammatuna M, Morabito A, Gennari L. Liver transplantation for the treatment of small hepatocellular carcinomas in patients with cirrhosis. $\mathrm{N}$ Engl J Med 1996;334:693-9.

14. Yao FY, Ferrell L, Bass NM, Watson JJ, Bacchetti P, Venook A, Ascher NL, Roberts JP. Liver transplantation 
for hepatocellular carcinoma: expansion of the tumor size limits does not adversely impact survival. Hepatology 2001;33:1394-403.

15. Scudamore $\mathrm{CH}$, Buczkowski AK, Shayan H, Ho SG, Legiehn GM, Chung SW, Owen DA. Mesohepatectomy. Am J Surg 2000;179:356-60.

16. Hu RH, Lee PH, Chang YC, Ho MC, Yu SC. Treatment of centrally located hepatocellular carcinoma with central hepatectomy. Surgery 2003;133:251-6.

17. Yamazaki S, Takayama T. Surgical treatment of hepatocellular carcinoma: evidence-based outcomes. World J Gastroenterol 2008;14:685-92.

18. Stratopoulos C, Soonawalla Z, Brockmann J, Hoffmann K, Friend PJ. Central hepatectomy: the golden mean for treating central liver tumors? Surg Oncol 2007;16:99-106.

19. Jarnagin WR, Gonen M, Fong Y, DeMatteo RP, Ben-Porat L, Little S, Corvera C, Weber S, Blumgart LH. Improvement in perioperative outcome after hepatic resection: analysis of 1,803 consecutive cases over the past decade. Ann Surg 2002;236:397-406; discussion 067.

20. Cho YB, Lee KU, Lee HW, Cho EH, Yang SH, Cho JY, Yi NJ, Suh KS. Outcomes of hepatic resection for a single large hepatocellular carcinoma. World J Surg 2007;31: 795-801.

21. Miyagawa S, Makuuchi M, Kawasaki S, Kakazu T. Criteria for safe hepatic resection. Am J Surg 1995;169: 589-94.

22. Giuliante F, Nuzzo G, Ardito F, Vellone M, De Cosmo G, Giovannini I. Extraparenchymal control of hepatic veins during mesohepatectomy. J Am Coll Surg 2008;206:496502.

23. Liu CL, Fan ST, Lo CM, Tung-Ping Poon R, Wong J. Anterior approach for major right hepatic resection for large hepatocellular carcinoma. Ann Surg 2000;232:2531.

24. Wu TJ, Wang F, Lin YS, Chan KM, Yu MC, Lee WC. Right hepatectomy by the anterior method with liver hanging versus conventional approach for large hepatocellular carcinomas. Br J Surg 2010;97:1070-8.

25. Chen XP, Qiu FZ, Wu ZD, Zhang BX. Hepatectomy for huge hepatocellular carcinoma in 634 cases. World $\mathrm{J}$ Gastroenterol 2006;12:4652-5.

26. Yamashita Y, Taketomi A, Itoh S, Kitagawa D, Kayashima H, Harimoto N, Tsujita E, Kuroda Y, Maehara Y. Longterm favorable results of limited hepatic resections for patients with hepatocellular carcinoma: 20 years of experience. J Am Coll Surg 2007;205:19-26.

27. Sakon M, Nagano H, Nakamori S, Dono K, Umeshita K, Murakami T, Nakamura H, Monden M. Intrahepatic recurrences of hepatocellular carcinoma after hepatectomy: analysis based on tumor hemodynamics. Arch Surg 2002;137:94-9.

28. Dahiya D, Wu TJ, Lee CF, Chan KM, Lee WC, Chen MF. Minor versus major hepatic resection for small hepatocel- lular carcinoma (HCC) in cirrhotic patients: a 20-year experience. Surgery 2010;147:676-85.

29. Ziparo V, Balducci G, Lucandri G, Mercantini P, Di Giacomo G, Fernandes E. Indications and results of resection for hepatocellular carcinoma. Eur J Surg Oncol 2002;28:723-8.

30. Matsui Y, Terakawa N, Satoi S, Kaibori M, Kitade H, Takai S, Kwon AH, Kamiyama Y. Postoperative outcomes in patients with hepatocellular carcinomas resected with exposure of the tumor surface: clinical role of the nomargin resection. Arch Surg 2007;142:596-602; discussion 03 .

31. Shah SA, Cleary SP, Wei AC, Yang I, Taylor BR, Hemming AW, Langer B, Grant DR, Greig PD, Gallinger $S$. Recurrence after liver resection for hepatocellular carcinoma: risk factors, treatment, and outcomes. Surgery 2007;141:330-9.

32. Farges O, Belghiti J, Kianmanesh R, Regimbeau JM, Santoro R, Vilgrain V, Denys A, Sauvanet A. Portal vein embolization before right hepatectomy: prospective clinical trial. Ann Surg 2003;237:208-17.

33. Palavecino M, Chun YS, Madoff DC, Zorzi D, Kishi Y, Kaseb AO, Curley SA, Abdalla EK, Vauthey JN. Major hepatic resection for hepatocellular carcinoma with or without portal vein embolization: Perioperative outcome and survival. Surgery 2009;145:399-405.

34. Sasaki Y, Yamada T, Tanaka H, Ohigashi H, Eguchi H, Yano M, Ishikawa O, Imaoka S. Risk of recurrence in a long-term follow-up after surgery in 417 patients with hepatitis B- or hepatitis C-related hepatocellular carcinoma. Ann Surg 2006;244:771-80.

35. Yeh CN, Lee WC, Chen MF, Tsay PK. Predictors of longterm disease-free survival after resection of hepatocellular carcinoma: two decades of experience at Chang Gung Memorial Hospital. Ann Surg Oncol 2003;10:916-21.

36. Fukuda S, Itamoto T, Amano H, Kohashi T, Ohdan H, Tashiro H, Asahara T. Clinicopathologic features of hepatocellular carcinoma patients with compensated cirrhosis surviving more than 10 years after curative hepatectomy. World J Surg 2007;31:345-52.

37. Hennessey DB, Burke JP, Ni-Dhonochu T, Shields C, Winter DC, Mealy K. Preoperative hypoalbuminemia is an independent risk factor for the development of surgical site infection following gastrointestinal surgery: a multiinstitutional study. Ann Surg 2010;252:325-9.

38. Jarnagin WR, Gonen M, Fong Y, DeMatteo RP, Ben-Porat L, Little S, Corvera C, Weber S, Blumgart LH. Improvement in perioperative outcome after hepatic resection: analysis of 1,803 consecutive cases over the past decade. Ann Surg 2002;236:406-7.

39. Poon RT, Fan ST, Lo CM, Liu CL, Lam CM, Yuen WK, Yeung $\mathrm{C}$, Wong J. Improving perioperative outcome expands the role of hepatectomy in management of benign and malignant hepatobiliary diseases: analysis of 1222 consecutive patients from a prospective database. 
Ann Surg 2004;240:698-708.

40. Hanazaki K, Kajikawa S, Shimozawa N, Shimada K, Hiraguri M, Koide N, Adachi W, Amano J. Hepatic resection for large hepatocellular carcinoma. Am J Surg 2002;181:347-53.

41. Park JH, Koh KC, Choi MS, Lee JH, Yoo BC, Paik SW, Rhee JC, Joh JW. Analysis of risk factors associated with early multinodular recurrences after hepatic resection for hepatocellular carcinoma. Am J Surg 2006;192:29-33.

42. Redmond HP, Leon P, Lieberman MD, Hofmann K, Shou J, Reynolds JV, Goldfine J, Johnston RB Jr, Daly JM. Impaired macrophage function in severe protein-energy malnutrition. Arch Surg 1991;126:192-6. 


\title{
中央區巨大肝細胞癌之手術治療
}

\author{
鄭志軒 游明晉 吴宗翰 李正方 詹昆明 周宏學 李威震
}

背景：中央區巨大肝細胞癌是外科手術中一個困難棘手的病症, 通常是以半/擴大或中央 肝切除術來治療。這個研究主要是探討半/擴大或中央肝切除術的治癒成效。

方 法: 將於我院進行肝切除的 104 位中央區巨大肝細胞癌病患區分爲 2 組, 群組 1 有 41 位 病患進行擴大的半肝切除; 群組 2 有 63 位病患進行以中央肝切除術, 針對 2 個群組 的群組特徵以及手術治療進行研究分析。

結 果: 針對群組 2 的病患進行肝切除手術, 其中群組 2 中有 $92.6 \%$ 的人切緣小於 1 公分, 而群組 1 中則有 $78.9 \%$ 的人切緣小於 1 公分 $(p=0.056)$ 。群組 1 的 1 年及 5 年存活率 分別爲 $50 \%$ 及 $38.9 \%$; 群組 2 的 1 年及 5 年存活率分別爲 $50 \%$ 及 $15 \%(p=0.279)$ 。 群組 1 的 1 年及 5 年存活率分別爲 $89.5 \%$ 及 $66.2 \%$; 群組 2 的 1 年及 5 年存活率分別 爲 $87.5 \%$ 及 $53.1 \%(p=0.786)$ 。肝硬化、血清麩胺酸苯醋酸轉氨基脢數値及切除肝臟 重量爲影響病患存活率的獨立因素。

結 論：擴大的半肝切除與中央肝切除的術後併發症及長期存活率相似。肝硬化、血清麩胺 酸苯醋酸轉氨基脢數值及切除肝臟重量與長期存活率具有顯著的關聯性。

(長庚醫誌 2012;35:178-91)

關鍵詞：肝癌, 中央肝切除手術, 半肝切除手術

長庚醫療財團法人林口長庚紀念醫院 肝臟移植外科 一般外科；長庚大學 醫學院

受文日期：民國100年3月29日；接受刊載：民國100年10月20日

通訊作者: 李威震醫師, 長庚醫療財團法人林口長庚紀念醫院 肝臟移植外科 一般外科。桃園縣 333 龜山郷復興街 5 號。

Tel: (03)3281200轉3366; Fax: (03)3285818; E-mail: weichen@cgmh.org.tw 